\title{
Technology implementation barrier of rural Malay herbal entrepreneurship in Malaysia
}

\begin{abstract}
Immense technology is used to enhance productivity and profit in herbal entrepreneurship. However, the implementation of technology is deemed to be lacking among Malay herbal entrepreneurs in Malaysia. Thus, the aim of this study was to identify factors that hinder rural Malay herbal entrepreneurs from using technology. A qualitative approach using case study in-depth interview was used to gather data from eight respondents who are actively involved in herbal entrepreneurship. The data revealed that most of the rural Malay herbal entrepreneurs are small in scale and they are lagging far behind in technology usage. Further analysis showed that technical specialist, capital and operational problems are barriers of technology usage among Malay herbal entrepreneurship. The study suggests that a combination of factors that include the role of government, family members, financial and human resources are pertinent in supporting extensive usage of technology among Malay herbal entrepreneurs.
\end{abstract}

Keyword: Technology implementation; Herbal industry; Entrepreneurship; Technology barrier; Small medium enterprise 